medRxiv preprint doi: https://doi.org/10.1101/2020.05.12.20099333; this version posted May 16, 2020. The copyright holder for this preprint

(which was not certified by peer review) is the author/funder, who has granted medRxiv a license to display the preprint in perpetuity.

All rights reserved. No reuse allowed without permission.

\title{
THE MUC5B PROMOTOR POLYMORPHISM ASSOCIATES WITH SEVERE COVID-19
}

\author{
Coline H.M. van Moorsel ${ }^{1,2^{*}}$, Joanne J. van der Vis ${ }^{1,3^{*}}$, Claudia Benschop ${ }^{1,4}$, Henk J.T. Ruven ${ }^{3}$, \\ Marian Quanjel ${ }^{1}$, Jan C. Grutters ${ }^{1,2}$ \\ ${ }^{1}$ St Antonius ILD Center of Excellence, Department of Pulmonology, St. Antonius Hospital, Nieuwegein, The Netherlands \\ ${ }^{2}$ Division of Heart and Lungs, University Medical Center Utrecht, Utrecht, The Netherlands \\ ${ }^{3}$ St Antonius ILD Center of Excellence, Department of Clinical Chemistry, St. Antonius Hospital, Nieuwegein, The Netherlands \\ ${ }^{4}$ St Antonius ILD Center of Excellence, Department of Medical Microbiology and Immunology, St. Antonius Hospital, Nieuwegein, \\ The Netherlands \\ *These authors contributed equally to the study
}

Corresponding author: Coline HM van Moorsel c.van.moorsel@antoniusziekenhuis.nl, Funding: ZonMW TopZorg St Antonius Care grant nr 842002001; ZonMW Topspecialistische Zorg en Onderzoek grant nr 10070012010004; Nederlandse Vereniging van Artsen voor Longziekten en

Tuberculose COVID-19 grant

\begin{abstract}
Background Diversity in response to exposition to severe acute respiratory syndrome coronavirus 2 (SARS-CoV-2) is common and may be related to the innate immune response. The mucin MUC5B is an important component of the innate immune response and expression levels are associated with the MUC5B promoter polymorphism, rs35705950. The high expressing T-allele of rs35705950 is an accepted risk allele for a non-infectious aging lung disease called idiopathic pulmonary fibrosis (IPF). However, given the theory of trade-offs in aging lung disease and the importance of high expression for an adequate immune response, we hypothesize that the T-allele is protective against severe coronavirus disease 2019 (COVID-19).

Methods We collected demographics, radiology, survival data and MUC5B rs35705950 allele status for 108 patients requiring hospitalisation for COVID-19 at St Antonius Hospital in The Netherlands. For comparison of allele frequencies and allele carriership with a white control cohort, the patient cohort was divided in a white $(n=83)$ and non-white cohort.
\end{abstract}

Results The patients had a median age of 66 years and consisted predominantly of males (74\%) and 23 patients $(21 \%)$ died. The T-allele frequencies of rs35705950 in white patients was 0.04 which was significantly lower than the T-allele frequency of 0.10 in white controls $(p=0.02)$. Moreover, comparison of the number of carriers and non-carriers of the $\mathrm{T}$ allele showed that only $8.4 \%$ of patients carried the $\mathrm{T}$ allele versus $18 \%$ of controls $(p=0.029$; $O R=0.41, \mathrm{Cl}=0.19-0.94$ ).

Conclusions The MUC5B rs35705950 promoter polymorphism associates with COVID-19. The risk allele (T) for IPF is protective against the development of severe COVID-19 disease. This is a further example of a trade-off between optimal expression levels in the respiratory system which associates with aging diseases. However, these results require further investigation. 
medRxiv preprint doi: https://doi.org/10.1101/2020.05.12.20099333; this version posted May 16, 2020. The copyright holder for this preprint (which was not certified by peer review) is the author/funder, who has granted medRxiv a license to display the preprint in perpetuity.

All rights reserved. No reuse allowed without permission.

\section{Introduction}

The current coronavirus disease COVID-19 pandemic illustrates the diversity in response to exposition to severe acute respiratory syndrome coronavirus 2 (SARS-CoV-2). Response to infection ranges between asymptomatic and death from organ failure, of which the latter is most commonly observed in the elderly 1. Such differences are associated with aging but may also be influenced by the genetic constitution of the host. However, to date genetic predisposing factors to COVID-19 are unknown.

Diversity in response to exposition to SARS-CoV-2 may be related to host factors associated with airway defense. The gel-forming mucin 5B (MUC5B) is part of the mucus that covers the surface of the respiratory epithelium and forms the first line of defense against respiratory pathogens. ${ }^{2,34}$. In vivo studies in mice showed that presence of Muc5B is essential for mucociliary clearance, a mechanism crucial for proper airway defense 5 . Mice heterozygous for a knock-out allele of Muc5B secreted approximately $50 \%$ of the wild-type level of Muc5b and demonstrate reduced mucociliary clearance ${ }^{5}$. Decreased mucociliary clearance is associated with aging in humans ${ }^{6}$ and with aging in mice ${ }^{7}$. Furthermore, aged mice with reduced mucociliary clearance had significantly reduced Muc5b levels in comparison with young mice ${ }^{7}$. Constitutive expression levels of MUC5B are associated with a common promoter polymorphism, rs35705950 of the encoding gene MUC5B. The minor rs35705950 T allele is associated with high expression levels of MUC5B and the major $\mathrm{G}$ allele is associated with low expression levels ${ }^{8,9}$. The high expressing T-allele is a known risk factor for idiopathic pulmonary fibrosis (IPF) ${ }^{8}$, a fatal aging lung disease of unknown cause predominately affecting older males with a history of smoking. IPF is a noninfectious disease of the distal lung, caused by damage of the alveolar epithelium following by progressive fibrogenesis ${ }^{10}$.

Recently it was shown that aging lung diseases such as IPF and COPD share disease loci but have opposite risk alleles ${ }^{11}$. Given the fact that the alleles of these loci influence expression levels we proposed a theory of trade-offs in aging lung disease ${ }^{12}$. A trade-off exists whenever a benefit in one context entails a cost in another ${ }^{13}$. In aging lungs, the high expressing MUC5B T-allele may be important for optimal airway defense against infections while it provides an increased risk for IPF in the alveolar compartment.

Therefore, we hypothesize that the high expressing MUC5B T-allele of rs35705950 is protective against development of severe COVID-19 disease. We expect that the frequency of the T-allele is significantly lower in patient with COVID-19 requiring hospitalization.

\section{Material and methods}

\section{Patients}


medRxiv preprint doi: https://doi.org/10.1101/2020.05.12.20099333; this version posted May 16, 2020. The copyright holder for this preprint (which was not certified by peer review) is the author/funder, who has granted medRxiv a license to display the preprint in perpetuity.

All rights reserved. No reuse allowed without permission.

In the study, 108 adult patients hospitalized with COVID-19 at St Antonius Hospital between March 19 2020 and May 52020 were included. Diagnosis of COVID-19 were made on the basis of a positive SARS-CoV-2 PCR except for three cases with clinical characteristics and a high-resolution computed tomography (HRCT) congruent with COVID-19 disease. We collected demographics, radiology and survival data from medical hospital records.

The control group consists of 611 Dutch white healthy controls. The study was approved by The Medical research Ethics Committees United (MEC-U) of St. Antonius Hospital and all patients provided written informed consent (approval number R05-08A).

\section{Genotyping}

DNA was extracted from whole blood and genotyped for MUC5B rs35705950 genotype with a predesigned taqman SNP genotyping assay (Applied Biosystems) and the QuantStudio 5 Real-Time PCR system (ThermoFisher Scientific, Waltham, Massachusetts, USA).

\section{Statistical analysis}

SPSS 24 (IBM, Armonk, New York, USA) was used for statistical analysis. Due to ethnic differences in the prevalence of the MUC5B rs35705950 alleles, genetic analyses were stratified by ethnicity and only statistically analyzed in white subjects. Differences between white and non-white patients and between carriers and non-carriers of the rs35705950 T-allele were calculated using a Chi square test for categorical data and Mann-Whitney-U test for non-parametric continuous data and t-test for parametric continuous data. Differences between the allele and genotype frequencies were calculated with the Pearson's goodness-of-fit chi-square test, together with the OR and 95\% Cl. Fisher's exact test was used to test for deviation from Hardy-Weinberg equilibrium. A value of $p<0.05$ was considered statistically significant.

\section{Results}

\section{Patients}

In total 108 patients hospitalized with COVID-19 (table 1) were included in the study of which 74 (69\%) were males. The median age of the patients was 66 years (range 19.1-92.4). Of all patients, 23 patients died $(21 \%)$ and they were significantly older than patients who survived, 74 versus 63 years respectively $(\mathrm{p}=0.002)$.

Among 108 patients, 83 (77\%) were white and 25 patients were non-whites. The median age at diagnosis differed significantly between whites ( 71 years) and non-whites ( 55 years; $p=0.0004$ ), and there was a trend towards significance for a younger age at death in non-whites (table 1). 
medRxiv preprint doi: https://doi.org/10.1101/2020.05.12.20099333; this version posted May 16, 2020. The copyright holder for this preprint (which was not certified by peer review) is the author/funder, who has granted medRxiv a license to display the preprint in perpetuity.

All rights reserved. No reuse allowed without permission.

Table 1. Characteristics of patients hospitalized with COVID-19.

\begin{tabular}{lcccc}
\hline & all & white & non-white & $\mathrm{p}$ \\
\hline $\mathrm{N}$ & 108 & 83 & 25 & \\
Males, n (\%) & $74(69)$ & $56(67)$ & $18(72)$ & $\mathrm{ns}$ \\
Median age at diagnosis, y & & & & \\
(range) & $66(19-92)$ & $71(19-92)$ & $55(28-80)$ & 0.001 \\
Deaths, n (\%) & $23(21)$ & $18(22)$ & $5(20)$ & $\mathrm{ns}$ \\
Median age at death, y (range) & $74(46-92)$ & $76(46-92)$ & $64(51-80)$ & 0.14
\end{tabular}

$\mathrm{N}=$ number, $\mathrm{y}=$ years, $\mathrm{ns}=$ not significant.

MUC5B rs35705950

In the total group of 108 patients, there were 99 patients with a GG genotype and 9 patients with a GT genotype. The minor T-allele frequency of the MUC5B promoter polymorphism was 0.04 . In the white subgroup of COVID-19 patients, 76 had a GG genotype and 7 a GT genotype, which was in HardyWeinberg equilibrium. The frequency of the T-allele in the white COVID-19 group was 0.04 and this was significantly lower than the T-allele frequency of 0.10 in the control group $(p=0.023$; $O R=0.42, C l=0.19$ 0.91). Moreover, comparison of the number of carriers and non-carriers of the T allele between patients and controls showed that only $8.4 \%$ of patients carried the minor allele versus $18 \%$ of controls $(p=0.029$; $\mathrm{OR}=0.41, \mathrm{Cl}=0.19-0.94$; table 2 ).

Table 2. MUC5B rs35705950 genotype of white subjects with COVID-19 and controls.

\begin{tabular}{lcccc}
\hline & COVID-19 & Controls & OR (Cl) & $\mathrm{p}$ \\
\hline $\mathrm{N}$ & 83 & 611 & & \\
$\mathrm{GG}, \mathrm{n}$ & 76 & 501 & & \\
$\mathrm{GT}, \mathrm{n}$ & 7 & 103 & & \\
$\mathrm{TT}, \mathrm{n}$ & 0 & 7 & & \\
MAF & 0.04 & 0.10 & $0.42(0.19-0.91)$ & 0.023 \\
T-carriers, n & 7 & 110 & $0.41(0.19-0.94)$ & 0.029 \\
\hline
\end{tabular}

$\mathrm{N}=$ number, $\mathrm{MAF}=$ minor allele frequency, $\mathrm{OR}=$ odds ratio, $\mathrm{Cl}=$ confidence interval.

\section{Discussion}

In this study we examined whether a genetic polymorphism that influences expression of MUC5B is associated with susceptibility to severe COVID-19 disease. We observed a significant association between the MUC5B rs35705950 promoter polymorphism and COVID-19 disease. The T-allele frequency 
medRxiv preprint doi: https://doi.org/10.1101/2020.05.12.20099333; this version posted May 16, 2020. The copyright holder for this preprint (which was not certified by peer review) is the author/funder, who has granted medRxiv a license to display the preprint in perpetuity. All rights reserved. No reuse allowed without permission.

and T-carrier frequency was lower in white hospitalized COVID-19 patients than in white controls, suggesting that the T-allele is protective against severe COVID-19 disease.

Beneficial effects of carriership of the T-allele have been reported before. In smoking non-Hispanic white COPD patients with interstitial HRCT features carriers experienced less acute respiratory disease and a longer time-to-first event ${ }^{14}$. Furthermore, in IPF patients, carriers had a lower bacterial burden than noncarriers ${ }^{15}$ and better survival ${ }^{16}$. In congruence with these finding, lower bacterial burden in IPF was associated with less disease progression ${ }^{17}$.

In the human respiratory system, MUC5B is secreted throughout the lung by submucosal glands and the superficial epithelium of trachea, bronchi, bronchioles and alveoli, and by salivary glands and nasal mucosa $3,5,18,19$. Carriers of the MUC5B T-allele demonstrated upregulated RNA expression of MUC5B in lung tissue 89 20. The increased MUC5B production in T-allele carriers may therefore protect carriers from adverse events related to airway defense. This may be of particular importance in aging subjects, because mucus production and mucociliary clearance have been described to decrease with natural aging ${ }^{6,21}$. Decreased mucociliary clearance may underlie the observed age-related increase in the incidence of severe community-acquired pneumonia in the elderly ${ }^{22}$. Similar to previous reports on COVID-19 ${ }^{1}$ we also observed that severe COVID-19 and death from COVID-19 is predominantly found in the elderly.

With increasing age, the lung changes to the extent that alleles which in younger people confer nonessential divergent expression, may start influencing the risk of disease development in aged tissue. In aging lung diseases such as IPF, COPD and lung cancer, a pattern is emerging of shared disease loci. Interesting however, diseases associate with opposite risk alleles, which oppositely influence expression levels ${ }^{11,12,23}$. Previously we summarized findings and presented a theory in which trade-offs between compartments of the aging respiratory system exist, with the different compartments requiring different optimal expression levels ${ }^{12}$.

The MUC5B rs35705950 polymorphism may be added to this list of shared loci, because the T-allele ,which appears beneficial in this and above described studies, is best known as a major risk allele for IPF 8. IPF is a rare non-infectious pulmonary aging disease of unknown cause characterized by insidious onset of disease in patients without a history of pulmonary infection. Subsequent research showed that the MUC5B T-allele not only predisposes to IPF but to a variety of chronic progressive forms of pulmonary fibrosis ${ }^{24-27}$. The key cell in the pathogenesis of pulmonary fibrosis is the alveolar type II (AT2) cell. Recent research showed that ectopic overproduction of Muc5b in AT2 cells in mice cause mucociliary dysfunction and bleomycin-induced pulmonary fibrosis ${ }^{19}$. Interestingly, overproduction in AT2 cells caused worse mucociliary dysfunction than overproduction in club cells in airways ${ }^{19}$.

The fact that the high expressing $T$ allele is associated with an increased risk for pulmonary fibrosis combined with the current and previous findings that the T-allele protects against severe COVID-19 and infectious burden is another example of a trade-off that arises with aging. During the first decades of life the effect of both alleles is neutral while at an older age differences in constitutive expression predispose 
medRxiv preprint doi: https://doi.org/10.1101/2020.05.12.20099333; this version posted May 16, 2020. The copyright holder for this preprint (which was not certified by peer review) is the author/funder, who has granted medRxiv a license to display the preprint in perpetuity.

All rights reserved. No reuse allowed without permission.

to disease. The price for enhanced expression in the airways and better defense against viral pathogens may be early aging of the alveolar compartment.

Although the finding is of interest it must be noted that the small sample size and the lack of replication is a major limitation of the current study. Furthermore, due to limited sample size we were not able to perform an association analysis in non-white subjects, while they suffer disproportionally from COVID-19. In conclusion, we found that the T-allele of MUC5B rs35705950 confers protection from development of severe COVID-19 disease. Because the T-allele is a known risk allele for pulmonary fibrosis, the study provides further evidence for the existence of trade-offs between optimal expression levels in the aging lung. Further studies with lager sample size are needed to understand the importance of our finding.

\section{Acknowledgement}

We thank Mirjam Visser for support in the patient informed consent procedure.

\section{Literature}

1. Rosenberg ES, Dufort EM, Blog DS, et al. COVID-19 Testing, Epidemic Features, Hospital Outcomes, and Household Prevalence, New York State-March 2020. Clin Infect Dis. May 2020. doi:10.1093/cid/ciaa549

2. Knowles MR, Boucher RC. Mucus clearance as a primary innate defense mechanism for mammalian airways. J Clin Invest. 2002;109(5):571-577. doi:10.1172/jci15217

3. Okuda K, Chen G, Subramani DB, et al. Localization of secretory mucins MUC5AC and MUC5B in normal/healthy human airways. Am J Respir Crit Care Med. 2019;199(6):715-727.

doi:10.1164/rccm.201804-0734OC

4. Zanin M, Baviskar P, Webster R, Webby R. The Interaction between Respiratory Pathogens and Mucus. Cell Host Microbe. 2016;19(2):159-168. doi:10.1016/j.chom.2016.01.001

5. Roy MG, Livraghi-Butrico A, Fletcher AA, et al. Muc5b is required for airway defence. Nature. 2014;505(7483):412-416. doi:10.1038/nature12807

6. Svartengren M, Falk R, Philipson K. Long-term clearance from small airways decreases with age. Eur Respir J. 2005;26(4):609-615. doi:10.1183/09031936.05.00002105

7. Grubb BR, Livraghi-Butrico A, Rogers TD, Yin W, Button B, Ostrowski LE. Reduced mucociliary clearance in old mice is associated with a decrease in muc5b mucin. Am J Physiol - Lung Cell Mol Physiol. 2016;310(9):L860-L867. doi:10.1152/ajplung.00015.2016

8. Seibold MA, Wise AL, Speer MC, et al. A common MUC5B promoter polymorphism and pulmonary fibrosis. N Engl J Med. 2011;364(16):1503-1512. doi:10.1056/NEJMoa1013660 
medRxiv preprint doi: https://doi.org/10.1101/2020.05.12.20099333; this version posted May 16, 2020. The copyright holder for this preprint (which was not certified by peer review) is the author/funder, who has granted medRxiv a license to display the preprint in perpetuity.

All rights reserved. No reuse allowed without permission.

9. Nakano Y, Yang I V., Walts AD, et al. MUC5B promoter variant rs35705950 affects MUC5B expression in the distal airways in idiopathic pulmonary fibrosis. Am J Respir Crit Care Med. 2016;193(4):464-466. doi:10.1164/rccm.201509-1872LE

10. Raghu G, Remy-Jardin M, Myers JL, et al. Diagnosis of idiopathic pulmonary fibrosis An Official ATS/ERS/JRS/ALAT Clinical practice guideline. Am J Respir Crit Care Med. 2018;198(5):e44-e68. doi:10.1164/rccm.201807-1255ST

11. Hobbs BD, de Jong K, Lamontagne M, et al. Genetic loci associated with chronic obstructive pulmonary disease overlap with loci for lung function and pulmonary fibrosis. Nat Genet. 2017;49(3):426-432. doi:10.1038/ng.3752

12. Van Moorsel CHM. Trade-offs in aging lung diseases: A review on shared but opposite genetic risk variants in idiopathic pulmonary fibrosis, lung cancer and chronic obstructive pulmonary disease. Curr Opin Pulm Med. 2018;24(3):309-317. doi:10.1097/MCP.0000000000000476

13. Gluckman PD, Low FM, Buklijas T, Hanson MA, Beedle AS. How evolutionary principles improve the understanding of human health and disease. Evol Appl. 2011;4(2):249-263. doi:10.1111/j.17524571.2010.00164.x

14. Ash SY, Harmouche R, Putman RK, et al. Association between acute respiratory disease events and the MUC5B promoter polymorphism in smokers. Thorax. February 2018. doi:10.1136/thoraxjnl-2017-211208

15. Molyneaux PL, Cox MJ, Willis-Owen SAG, et al. The role of bacteria in the pathogenesis and progression of idiopathic pulmonary fibrosis. Am J Respir Crit Care Med. 2014;190(8):906-913. doi:10.1164/rccm.201403-05410C

16. Peljto AL, Zhang Y, Fingerlin TE, et al. Association between the MUC5B promoter polymorphism and survival in patients with idiopathic pulmonary fibrosis. JAMA - J Am Med Assoc.

2013;309(21):2232-2239. doi:10.1001/jama.2013.5827

17. Invernizzi R, Barnett J, Rawal B, et al. Bacterial burden in the lower airways predicts disease progression in idiopathic pulmonary fibrosis and is independent of radiological disease extent. Eur Respir J. 2020;55(4). doi:10.1183/13993003.01519-2019

18. Nielsen PA, Bennett EP, Wandall HH, Therkildsen MH, Hannibal J, Clausen $\mathrm{H}$. Identification of a major human high molecular weight salivary mucin (MG1) as tracheobronchial mucin MUC5B. Glycobiology. 1997;7(3):413-419. doi:10.1093/glycob/7.3.413

19. Hancock LA, Hennessy CE, Solomon GM, et al. Muc5b overexpression causes mucociliary dysfunction and enhances lung fibrosis in mice. Nat Commun. 2018;9(1). doi:10.1038/s41467018-07768-9

20. Helling BA, Gerber AN, Kadiyala V, et al. Regulation of MUC5B expression in idiopathic pulmonary fibrosis. Am J Respir Cell Mol Biol. 2017;57(1):91-99. doi:10.1165/rcmb.2017-0046OC

21. Ho JC, Chan $\mathrm{KN}, \mathrm{Hu} \mathrm{WH}$, et al. The effect of aging on nasal mucociliary clearance, beat frequency, and ultrastructure of respiratory cilia. Am J Respir Crit Care Med. 2001;163(4):983-988. 
medRxiv preprint doi: https://doi.org/10.1101/2020.05.12.20099333; this version posted May 16, 2020. The copyright holder for this preprint

(which was not certified by peer review) is the author/funder, who has granted medRxiv a license to display the preprint in perpetuity.

All rights reserved. No reuse allowed without permission.

doi:10.1164/ajrccm.163.4.9909121

22. Fung HB, Monteagudo-Chu MO. Community-acquired pneumonia in the elderly. Am J Geriatr Pharmacother. 2010;8(1):47-62. doi:10.1016/j.amjopharm.2010.01.003

23. Snetselaar R, van Oosterhout MFM, Grutters JC, Van Moorsel CHM. TERT polymorphism rs2736100: a balancing act between cancer and non-cancer disease, a meta-analysis. Front Med. 2018;5:41. doi:10.3389/FMED.2018.00041

24. Van Der Vis JJ, Snetselaar R, Kazemier KM, Ten Klooster L, Grutters JC, Van Moorsel CHM. Effect of Muc5b promoter polymorphism on disease predisposition and survival in idiopathic interstitial pneumonias. Respirology. 2016;21(4):712-717. doi:10.1111/resp.12728

25. Ley B, Newton CA, Arnould I, et al. The MUC5B promoter polymorphism and telomere length in patients with chronic hypersensitivity pneumonitis: an observational cohort-control study. Lancet Respir Med. 2017;5(8):639-647. doi:10.1016/S2213-2600(17)30216-3

26. Platenburg MGJP, Wiertz IA, van der Vis JJ, et al. The MUC5B promoter risk allele for idiopathic pulmonary fibrosis predisposes to asbestosis . Eur Respir J. January 2020:1902361. doi:10.1183/13993003.02361-2019

27. Juge PA, Lee JS, Ebstein E, et al. MUC5B promoter variant and rheumatoid arthritis with interstitial lung disease. N Engl J Med. 2018;379(23):2209-2219. doi:10.1056/NEJMoa1801562 